Journal of Engineering and Applied Sciences 15 (7): 1659-1663, 2020

ISSN: 1816-949X

(C) Medwell Journals, 2020

\title{
Awareness Raising of Marine Biodiversity and Plant Genetic Diversity Through Drama Process
}

\author{
Pimonpan Lertlum \\ Faculty of Music and Performing Arts, Burapha University, 169 Long Had Bangsaen, \\ Sansuk, Muang, Chonburi, Thailand
}

\begin{abstract}
According to the economic prosperity in the Eastern region, the environmental problems have been formed. The destruction of environment; waste water from industrial sectors, release of oil and spoilage from fisheries, space invasive for tourism business has been done by local people and tourists. Social awareness, the ability to take the perspective of and empathize with others is essential for being a part of the community and environment. Performing arts is one of the communicating tools to transmit emotion, thinking through the process of arts and reflect certain fact or information through the production of data searching with site survey for creating and developing the drama show's script. The purposes of the study were to process the performance for publicizing the contents of the conservation of marine biodiversity and plant genetic diversityand to create learning behavior and awareness of youth people in the conservation of marine biodiversity and plant genetic diversity. Participants in this study were 1628 elementary students, teachers and school administrators of 20 elementary schools in Eastern region. The contents of the ecosystem of the mangrove forest which were suitable for the elementary school students were selected to create a script's outline. The performing script was divided into 5 partsand presented in the form of comedy. Pre-test and post-test about the marine and ecosystem's knowledge for students were done. The paired t-test was used to determine if there was significantly different. In addition, 5-point Likert scale questionnaires based on the satisfaction and suggestion for teachers and school administrators were done. The descriptive mean of satisfaction was reported. The results showed that after watching the drama show, the students significantly increased more knowledge, both each school and overall. The results of the survey of overall satisfaction with the drama show revealed that the appropriateness of the content presented to the audience and the content is consistent with the context of the area were the highest. In summary, the drama show was a media that provided knowledge to children for understanding in conservation and development of the mangrove forest.
\end{abstract}

Key words: Awareness, marine biodiversity, plant genetic diversity, drama process, satisfaction

\section{INTRODUCTION}

The Eastern region of Thailand has been geographically characterized into mountain range, lowland and coastal plain, includes 7 provinces; Sa Kaeo, Chonburi, Rayong, Chantaburi, Chachoengsao, Trat and Prachinburi. Most of them locate nearby the sea with beautiful landscape such as bays, capes, islands (Siriwat, 2000). There is a wide variety of an abundance of resources in the Eastern region including natural, economical and industrial resources. According to the economic prosperity in this region, the environmental problems have been formed. The destruction of environment; waste water from industrial sectors, release of oil and spoilage from fisheries, space invasive for tourism business has been done by local people and tourists (Sanit, 1998).

Social awareness is defined as the ability to take the perspective of and empathize with others including those from diverse backgrounds and cultures (CASEL., 2019). It is essential for people to understand and respond to the needs of others, to learn the role of social co-existence and appropriate behavior in building a relationship between people in the community. Since, everyone is a part of the community and environment, following the rules and regulation of the community is the responsibility of the community's members to behave appropriately and respect the differences.

There are several ways people use for communication. Performing arts is one of the communicating tools to transmit emotion, thinking through the process of arts. It is likely the media for others to perceive and understand what we want to objectively inform. The performances usually reflect certain fact or information through the production of data searching with site survey for creating and developing the drama show's script. It is believed that human thinking and living skills can be clearly developed by arts. Awareness raising of marine biodiversity and plant genetic diversity through drama process is the analytic process from several resources and delivers through drama process for communicating with audiences what 
we want them to perceive and think along with the performance. This is the tool and the media to reduce gap between people or people and organization (Sarayuth and Buasalee, 2011). The purposes of the study were to process the performance for publicizing the contents of the conservation of marine biodiversity and plant genetic diversity and to create learning behavior and awareness of youth people in the conservation of marine biodiversity and plant genetic diversity.

\section{MATERIALS AND METHODS}

Participants in this study were the elementary students, teachers and school administrators of 20 elementary schools in Eastern region. All participants were informed about the purposes, procedures and advantages of the study including inclusion and exclusion criteria, then the consent forms were signed.

Procedures: The contents of the ecosystem of the mangrove forest which were suitable for the elementary school students were selected to create a script's outline. The performing script was divided into 5 parts; the important and characteristics of mangrove forest, the animals in mangrove forest, the plants in mangrove, the impact of mangrove forest's destruction by human and the conservation of mangrove forest. The performance was presented in the form of comedy. It combined the humor between characters and events which those characters have to face. The audiences were included to be part of the story for learning and participating through the characters and events. The researcher wanted them to understand and learn about the marine and plant genetic diversities in the mangrove forest and aware of the relationship between living and conservation by using the drama process in knowledge sharing. The drama process was organized as follow:

All participants answered the paper test about the knowledge of the marine and plant genetic diversities in the mangrove forest before the drama show. The drama show "the mangrove forest and friends" had continued for $1 \mathrm{~h}$.

All participants answered the paper test about the knowledge of the marine and plant genetic diversities in the mangrove forest after the drama show.

In addition, the questionnaire was generate based on the satisfaction and suggestion with a 5-point Likert scale for teachers and school administrators. All data were conduct using statistical software analysis. The descriptive mean and standard deviation of secondary target group including school administrators, teachers, academic staff of satisfaction of the drama show was done. The paired t-test was used to determine if there was significantly different $(p<0.05)$ in the knowledge about mangrove forest andmarine and plant genetic diversities between before and after watching the drama show.

\section{RESULTS AND DISCUSSION}

This research's objective of the study were to process the performance for publicizing the contents of the conservation of marine biodiversity and plant genetic diversity and to create learning behavior and awareness of youth people in the conservation of marine biodiversity and plant genetic diversity. The information was analyzed, described and presented in tables. 1628 students of 20 schools in Eastern region were asked to do the questionnaires about mangrove forest and marine and plant genetic diversities before and after watching the drama show. The results showed that after watching the drama show, the students significantly increased more knowledge about mangrove forest andmarine and plant genetic diversities $(p=0.000)$ both each school and overall as shown in Table 1.

From the supporting of the secondary target group including the school administrators, teachers and academic staff, the students would obtain these knowledge, share and learn between schools in the region with long-term benefit in the future which corresponds with Plant Genetic Conservation Project under the Royal Initiation of Her Royal Highness Princess Maha Chakri Sirindhorn (RSPG).

Secondary target groups that were involved in promoting and developing knowledge for the students, were the female class teachers, age between 31 and 40 years old, Bachelor's degree (Table 2). They completed the satisfaction questionnaires on the drama show of mangrove forest and friends in creating awareness about marine diversity and plant genetics through creative drama to be a reflection of the results of theatrical performances in the overall process.

The results of the survey of overall satisfaction with the drama show revealed in Table 3 that the appropriateness of the content presented to the audience is consistent with the context of the area were the highest mean of $4.52+0.58$ and $4.52+0.51$, respectively. The appropriateness of bringing drama into learning media and overview of the show were the second order with mean value of $4.48+0.64$ and $4.48+0.51$, respectively.

Theater for transformation is the application of the applied theater to develop participants, both as a performer and an audience in every step of drama processes with the goal to enable participants to develop their personal resources by focusing on the learning process to change 4 levels as follows (Pareuhas, 2014):

Individual level changes by focusing on the internal learning process to develop physical, mental, intellectual for understanding themselves and others, understand humanity with subtlety, aesthetics.

Group level changes; the learning and creating of theater production develops the drama show from real life experiences. It helps participants to open their mind, listen 
J. Eng. Applied Sci., 15 (7): 1659-1663, 2020

Table 1: Comparison the differences of the mean score of knowledge about mangrove forest and marine and plant genetic diversities between before and after watching the drama show

\begin{tabular}{|c|c|c|c|c|c|c|}
\hline Schools & Test & $\mathrm{N}$ & - & SD & t-values & p-values \\
\hline \multirow[t]{2}{*}{ 1st school } & Pre & 41 & 6.93 & 1.89 & 8.355 & $0.000^{*}$ \\
\hline & Post & 41 & 8.63 & 1.87 & & \\
\hline \multirow[t]{2}{*}{ 2nd school } & Pre & 48 & 7.02 & 1.99 & 6.675 & $0.000 *$ \\
\hline & Post & 48 & 8.69 & 1.49 & & \\
\hline \multirow[t]{2}{*}{ 3rd school } & Pre & 41 & 7.07 & 1.57 & 9.731 & $0.000 *$ \\
\hline & Post & 41 & 9.10 & 1.34 & & \\
\hline \multirow[t]{2}{*}{ 4th school } & Pre & 48 & 6.13 & 1.90 & 8.038 & $0.000 *$ \\
\hline & Post & 48 & 8.08 & 2.06 & & \\
\hline \multirow[t]{2}{*}{ 5th school } & Pre & 52 & 6.12 & 2.13 & 6.669 & $0.000^{*}$ \\
\hline & Post & 52 & 7.83 & 1.90 & & \\
\hline \multirow[t]{2}{*}{ 6th school } & Pre & 56 & 6.13 & 1.79 & 5.946 & $0.000 *$ \\
\hline & Post & 56 & 7.63 & 2.62 & & \\
\hline \multirow[t]{2}{*}{ 7th school } & Pre & 60 & 6.18 & 1.72 & 12.522 & $0.000 *$ \\
\hline & Post & 60 & 8.75 & 1.74 & & \\
\hline \multirow[t]{2}{*}{ 8th school } & Pre & 58 & 5.90 & 1.66 & 9.408 & $0.000^{*}$ \\
\hline & Post & 58 & 8.07 & 1.77 & & \\
\hline \multirow[t]{2}{*}{ 9th school } & Pre & 69 & 6.71 & 1.16 & 10.147 & $0.000 *$ \\
\hline & Post & 69 & 8.51 & 1.34 & & \\
\hline \multirow[t]{2}{*}{ 10th school } & Pre & 103 & 6.93 & 1.47 & 11.370 & $0.000^{*}$ \\
\hline & Post & 103 & 8.81 & 1.56 & & \\
\hline \multirow[t]{2}{*}{ 11th school } & Pre & 66 & 6.94 & 1.63 & 8.888 & $0.000 *$ \\
\hline & Post & 66 & 8.50 & 1.66 & & \\
\hline \multirow[t]{2}{*}{ 12th school } & Pre & 100 & 5.67 & 1.85 & 9.753 & $0.000 *$ \\
\hline & Post & 100 & 7.42 & 2.23 & & \\
\hline \multirow[t]{2}{*}{ 13th school } & Pre & 138 & 5.22 & 1.60 & 12.639 & $0.000 *$ \\
\hline & Post & 138 & 7.68 & 2.08 & & \\
\hline \multirow[t]{2}{*}{ 14th school } & Pre & 107 & 6.28 & 1.87 & 10.990 & $0.000^{*}$ \\
\hline & Post & 107 & 8.12 & 1.86 & & \\
\hline \multirow[t]{2}{*}{ 15th school } & Pre & 93 & 6.01 & 1.75 & 14.081 & $0.000^{*}$ \\
\hline & Post & 93 & 8.37 & 1.77 & & \\
\hline \multirow[t]{2}{*}{ 16th school } & Pre & 59 & 5.46 & 1.99 & 7.354 & $0.000^{*}$ \\
\hline & Post & 59 & 6.95 & 2.38 & & \\
\hline \multirow[t]{2}{*}{ 17th school } & Pre & 59 & 4.51 & 1.85 & 6.759 & $0.000 *$ \\
\hline & Post & 59 & 5.92 & 2.60 & & \\
\hline \multirow{2}{*}{ 18th school } & Pre & 133 & 5.90 & 1.82 & 11.056 & $0.000^{*}$ \\
\hline & Post & 133 & 7.65 & 1.88 & & \\
\hline \multirow[t]{2}{*}{ 19th school } & Pre & 144 & 6.36 & 2.09 & 9.654 & $0.000^{*}$ \\
\hline & Post & 144 & 7.74 & 2.15 & & \\
\hline \multirow[t]{2}{*}{ 20th school } & Pre & 153 & 6.37 & 1.64 & 11.897 & $0.000^{*}$ \\
\hline & Post & 153 & 8.41 & 1.94 & & \\
\hline \multirow[t]{2}{*}{ Total } & Pre & 1628 & 6.14 & 1.86 & 41.868 & $0.000^{*}$ \\
\hline & Post & 1628 & 8.01 & 2.05 & & \\
\hline
\end{tabular}

*Significant $<0.05$ level

Table 2: General information of the secondary target group

\begin{tabular}{lrc}
\hline Items & $\mathrm{N}=27$ & Percentage \\
\hline Gender & 5 & \\
Male & 22 & 18.5 \\
Female & & 81.5 \\
Age (years) & 2 & 7.4 \\
$20-30$ & 14 & 51.9 \\
$31-40$ & 6 & 22.2 \\
$41-50$ & 5 & 18.5 \\
$>50$ & 14 & \\
Educational level & 10 & 53.8 \\
Bachelor & 2 & 38.5 \\
Master & & 7.7 \\
Others & 6 & \\
Status & 16 & 22.2 \\
Administrators & 2 & 59.3 \\
Class teacher & 3 & 7.4 \\
Assistant teacher & & 11.1 \\
Course teacher & &
\end{tabular}

to and accept different opinions, focus on building teamwork skills, overcome problems and obstacles with team goals.
Community level change; community drama practice learns from the drama production process, issues and community intelligence to reflect the story for the community to make a dialogue, seek ways to solve community problems together and live peacefully on various differences. This aims to create the learning from social issues to develop public mind and citizenship.

Social change, in-depth drama practice and in-depth theater arts practice can develop the capability of performing arts of the company to a semi-professional theater company who can reflect the potential contemporary phenomenon of society. This can inspire the audience to change with the ability to manage company to proceed the drama show continuously and efficiently.

The advantage of using drama media is that the drama media is culturally appropriate and sensitive to the context. It means that the drama media has a way to tell the stories along with the nature of the community. The 
J. Eng. Applied Sci., 15 (7): 1659-1663, 2020

Table 3: Satisfaction on the drama show

\begin{tabular}{llll}
\hline Satisfaction on the drama show & $\mathrm{N}$ & - & SD \\
\hline Preparation & 16 & 4.31 & 0.60 \\
The sequences in preparing to create understanding for the audience & 27 & 4.30 & $\mathbf{4 . 5 2}$ \\
The appropriateness of the content presented to the audience & 27 & 4.37 & 0.54 \\
The appropriateness of the time shown & 27 & 4.41 & 0.58 \\
Using the voice/dialogue of the characters & 27 & 4.37 & 0.63 \\
The appropriateness of the characters presented & 27 & 4.33 & 0.64 \\
The appropriateness of the garment & 27 & 4.30 & 0.56 \\
The appropriateness of the scene and equipment for performances & 27 & 4.48 \\
Overview of the show & 27 & 4.44 & 0.62 \\
The content is consistent with the educational policy & 27 & 4.37 & 0.51 \\
The content is consistent with the context of the area & 27 & $\mathbf{4 . 4 8}$ & 0.64 \\
The content is consistent with the learning content in the course & 27 & 4.04 & 0.58 \\
The appropriateness of bringing drama into learning media & 27 & 4.44 & 0.49 \\
Students' knowledge and understanding before watching the show & 27 & 0.64 \\
Knowledge and understanding of students after watching the show & & 0.85 \\
\hline
\end{tabular}

Bold values are significant

story is of the community itself, it is the vehicle of direct communication of information, issues, stories, content from real issues. It can serve the community as a "Media for change" because the community drama media will not only act to reflect problems or phenomena but aim to create a process to seek out a common solution for all parties in the community as well. In addition, it is able to record performance for further publicity

Pareuhas (2014), the Folk Media Foundation (MakhamPom), Head of the Theater for Transformation Network for Youth Network stated that the drama process aimed to realize the truth, know the reason, know the result, understand and appreciate self-worth and volunteer development through the group process. It included the creation and development of a network of drama operatives for change to drive the mechanism to create space and intellectual creative activities for youth through the art of drama with a network of theater actors and teachers in all 6 areas, covering the whole country.

"Creating citizens who contribute to the problems of communities and society is a great need for Thai society during the transition period. Learning of youth people such as promotes thinking processes, critical analysis and communicates ideas for solving problems equally is the essential skills in the 21st century. I believe that the drama process will help training these skills because the drama is interested in human being".

The impacts of the changes that occurred from the Eastern Region Development Plan, therefore were risen the questions to the researcher on how to make students in the eastern region who were close to and live in relation to marine resources at all times and were mostly born in the Eastern region, realized the importance to their existing natural resources (Waranuch, 2010). People in the community recognized and be aware of the situation in the area. How were the youth leaders drawnto value their homeland. When the drama process was used to be the media to educate students in the 20 schools of Eastern region. It was found that the beginning of this research could create the dimension of residents, understanding, respect, knowledgeable co-existence and ready to take care of the Eastern region through the capacity of the new youth generation, adult who were ready to support both the public and private sectors. We will be able to step through the varieties and ready to learn together with the community until learning innovation is created through the drama process.

\section{CONCLUSION}

After watching the drama processes created from the content of marine diversity and plant genetics, the children got more understanding. It allowed students to understand some methods of conserving and preserving mangrove forests as well as animals and plants in nearby areas. The students who lived in the adjacent areas to the mangrove forest, can integrate knowledge to use in real life. It is consistent with the teachers and school administrators in the area who recognized that the content is appropriate to the area context. Moreover, the drama show was also a media that provided knowledge to children as well as fulfilled the royal initiative to create new knowledge and understanding for various agencies and communities to involve in conservation and development of the mangrove forest to be abundant.

\section{REFERENCES}

CASEL., 2019. Core SEL competencies. Collaborative For Academic, Social And Emotional Learning (CASEL), Chicago, Illinois, USA. http://www.casel.org/social-and-emotional-learning /core-competencies/

Pareuhas, P.K., 2014. Widsom seed 3. Thai Health Promotion Foundation, Bangkok, Thailand. 
Sanit, A., 1998. Mangrove Forest Ecosystem and Management. 2nd Edn., Kasetsart University, Bangkok, Thailand,.

Sarayuth, B. and R. Buasalee, 2011. Mangrove Forest Ecosystem and Plants. 1st Edn., Rabbit in the Moon Foundation, Bangkok, Thailand,.
Siriwat, P., 2000. Mangrove Forest Ecosystem. 1st Edn., Sea National Park, Office of Natural Resources Revenue, Washington, D.C., USA.,.

Waranuch, S., 2010. Mangrove Forest: The Seashore Treasure. 1st Edn., Rak Thai Foundation, Bangkok, Thailand,. 